\title{
Comparative Analyses of Canadian and American Environmental Policy: An Introduction to the Symposium
}

\author{
Barry G. Rabe and William R. Lowry
}

Canada and the United States offer an intriguing basis for comparative analysis in environmental policy. Canadian and American policymakers often face the same challenges and pursue similar, if not identical, goals. Yet, the pursuit of those goals and the final outcomes can differ dramatically. Given all the dimensions on which these two countries are comparable, we thus are left with a puzzle. How can we explain the different experiences of the two nations?

In this article, we pose some answers to that question and preview the empirical analyses that follow. In short, we suggest that in spite of substantial common ground between the two nations, significant institutional differences exist that shape policy behavior and subsequent outcomes. We posit the importance of differences in intergovernmental relations, legislative-executive behavior, and systems of regulatory policymaking. After discussing the comparability of environmental policy in these two nations, we discuss those institutional differences and then offer some theoretical expectations for the cases to follow.

\section{Common Ground}

Canadians and Americans share more than a continent. Common roots in history, culture, and legal traditions are durable and still important. Largely because these two nations do share the continent, however, commonalities involving environmental issues are particularly intriguing. The border provides no barrier to pollutants traveling on air and water currents nor to migratory wildlife. Cross-boundary environmental concerns are longstanding, dating back to the formation of the International Joint Commission in 1909. Since then, sharing of the environment has caused some cooperation and even more tension between the two nations (Caldwell, 1985; Clarkson, 1982).

Moreover, both nations have a tradition of sharing regulatory strategies, environmental technologies, and policy goals. Sharing is a logical result of the fact that the two countries face common, persistent challenges in environmental issues such as long-term provision of goods to future generations, intractable conflicts between different advocacy groups, and the utilization of science in pursuing political outcomes. As the articles included in this symposium show, the countries continue to try to deal with these challenges with common environmental goals such as improved air quality, sustainable forestry, integrated approaches to pollution control, and scientific expansion of systems of protected areas.

Perhaps the common features between them are one reason for a rather surprising lack of comparative analysis regarding the two nations. The comparative environmental policy literature is growing, but the areas included in analyses usually have been the United States, Europe, and Japan, but rarely Canada (Heidenheimer, Heclo, \& Adams, 1990; Lundqvist, 1980; Nivola, 1997; Vogel, 1986). Only recently have scholars turned their comparative lenses to Canadian 
and American experiences (Harrison \& Hoberg, 1991; Hoberg, 1992; Lowry, 1994; Nemetz, 1986; Nemetz, Stanbury, \& Thompson, 1986; Rabe, 1994).

\section{Institutional Differences}

The growing Canadian-American comparative literature provides a foundation for systematic analyses of specific policy experiences in the two nations. This literature has roots in broad comparative studies of political processes that include a variety of factors such as historical experiences, socioeconomic conditions, mass political behavior, statutory as well as nonstatutory variables, and institutional relations between political actors that shape policy formation and implementation (Hofferbert, 1970; Sabatier \& Mazmanian, 1980). Largely due to similarities in many of the broad historical and economic variables, differences in institutional relations have become the focus of many recent analyses. Institutional differences between the two nations lead to theoretical expectations of varying processes and outcomes. Specifically, the case studies in this symposium emphasize three institutional differences.

\section{Federalism}

While both nations are federal systems, they take very different approaches to intergovernmental allocations of environmental policy responsibilities. Canada is a model of extreme decentralization among Western democracies. Constitutional mandates and political realities preclude a significant federal role in environmental issues (Cairns, 1992; Nemetz, 1986). The United States offers a more mixed approach to intergovernmental relations, with the federal government retaining substantial control over many environmental policies (Lowry, 1992; Rabe, 1997; Ringquist, 1993; Scheberle, 1997). As a result, Canadian provincial governments are more powerful, more independent, and more influential than are American state governments in most issues of environmental policy (Hoberg, 1992; Rabe, 1994).

\section{Legislative-Executive Relations}

The different formal structures of government in Canada and the United States lead to different relations between the legislative and executive branches (Lipset, 1990). The Canadian Westminster-style parliamentary system relies on disciplined political parties and members of the majority serving as cabinet ministers. In the United States, the president and legislators are elected separately, party discipline often is low, and heads of agencies are appointed, generally subject to approval by the Senate. Overall, the Westminster framework fosters more deference to the bureaucracy and relatively autonomous agency behavior (Campbell, 1983; Franks, 1987; Lowry, 1994). The American bureaucracy often is pulled back and forth by the Congress and the White House as well as by individual, entrepreneurial legislators (Heclo, 1977; Weaver \& Rockman, 1993).

\section{Regulatory Styles}

The American system of regulatory politics is inherently more adversarial than the Canadian one. While Canadian policymakers are more likely to pursue collaborative efforts, cultural and constitutional factors in the United States assure far greater recourse to the judiciary and much less consensus-building on environmental issues (Rabe, 1994; Vogel, 1986, p. 267). 


\section{Theoretical Expectations}

How will these institutional differences impact environmental policy in these two nations? As the following papers suggest, progress in the pursuit of similar goals generally is limited, although often for different reasons.

\section{Innovation Depends on Politics, Not Science}

Policy participants in both nations call for innovative solutions to resolve seemingly intractable problems such as toxic disposal and acid rain. Solutions are proposed, often grounded in scientific reason or empirical experience on a limited basis. Implementation of proposals such as pollution prevention, however, is shaped by the institutions described above. Scientific arguments in the United States become simply ammunition for adversarial processes. Development of scientific proposals in Canada often lags behind, left to provincial governments without supportive resources.

\section{The Future Remains Now}

Largely because the subject of policy goals are environmental outcomes, much official rhetoric in both nations focuses on future generations. Yet, the delivery of intergenerational goods such as preserved lands or renewable forests is limited substantially by a political emphasis on the short term. This emphasis generally is made manifest in the United States through political micromanagement of agency behavior. Those pursuing intergenerational goods in Canada necessarily must deal with political circumstances at the provincial level.

\section{Delegation is a Means, but to What End?}

Much of the recent focus on these policies in both nations suggests delegation as a means to more positive outcomes. Delegation advocates emphasize either decentralization to subnational governments or deference to public agencies. As these empirical analyses show, however, delegation without meaningful goals and real commitment simply transfers the processes of bargaining and compromise either to the subnational level or to an arena where bureaucrats are even more susceptible to political influence.

\section{Conclusion}

Explanations of variance between nations pursuing similar policy goals benefit from examination of the institutional context in which pursuit occurs. The environmental policy process in Canada and the United States may be quite similar at the beginning and even comparable at the end in terms of limited success. What happens in between often is quite different in the two nations, shaped by the important institutions of federalism, legislative-executive relations, and regulatory style.

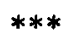

Barry G. Rabe is professor in the School of Natural Resources and Environment at the University of Michigan, Ann Arbor, MI 48109-1115. 
William R. Lowry is a member of the faculty of the Department of Political Science at Washington University in St. Louis, MO.

\section{Notes}

We are grateful to the late Don Hadwiger for the invitation to develop this symposium and to David Feldman for his considerable assistance as symposium coordinator. We also appreciate the thoughtful comments of two anonymous reviewers and of Michael Kraft who served as discussant on a 1997 Midwest Political Science Association Annual Meeting panel where earlier drafts of several of the papers included in the symposium were presented.

\section{References}

Caims, R. D. (1992). Natural resources and Canadian federalism. Publius, 22, 55-70.

Caldwell, L. K. (1985). Binational responsibilities for a shared environment. In C. F. Doran \& J. H. Sigler (Eds.), Canada and the United States (pp. 203-230). Englewood Cliffs, NJ: Prentice-Hall.

Campbell, C. (1983). Governments under stress. Toronto: University of Toronto Press.

Clarkson, S. (1982). Canada and the Reagan challenge. Toronto: Canadian Institute for Economic Policy.

Franks, C. E. S. (1987). The parliament of Canada. Toronto: University of Toronto Press.

Harrison, K., \& Hoberg, G. (1991). Setting the environmental agenda in Canada and the United States: The case of dioxin and radon. Canadian Journal of Political Science, 24, 3-27.

Heclo, H. (1977). A government of strangers. Washington, DC: Brookings.

Heidenheimer, A. J., Heclo, H., \& Adams, C. T. (1990). Comparative public policy (3rd ed.). New York, NY: St. Martin's.

Hoberg, G. (1992). Comparing Canadian performance in environmental policy. In R. Boardman (Ed.), Canadian environmental policy: Ecosystems, politics, and process (pp. 246-262). Toronto: Oxford University Press.

Hofferbert, R. I. (1970). Elite influence in state policy formation. Polity, 2(3), 316-344.

Lipset, S. M. (1990). Continental divide: The values and institutions of the United States and Canada. New York, NY: Routledge.

Lowry, W. R. (1992). The dimensions of federalism. Durham, NC: Duke University Press.

Lowry, W. R. (1994). The capacity for wonder. Washington, DC: Brookings.

Lundqvist, L. (1980). The hare and the tortoise. Ann Arbor, MI: University of Michigan Press.

Nemetz, P. (1986). Federal environmental regulation in Canada. Nalural Resources Journal, 26, 552608.

Nemetz, P., Stanbury, W. T., \& Thompson, F. (1986). Social regulation in Canada. Policy Studies Journal, 14, 580-603.

Nivola, P. S. (Ed.). (1997). Comparative disadvantages? Social regulations and the global economy. Washington, DC: Brookings.

Rabe, B. G. (1994). Beyond NIMBY. Washington, DC: Brookings.

Rabe, B. G. (1997). Power to the states: The promise and pitfalls of decentralization. In N. J. Vig \& M. E. Kraft (Eds.), Environmental policy in the 1990s: Reform or reaction? (3rd ed.) (pp. 31-52). Washington, DC: CQ Press.

Ringquist, E. J. (1993). Environmental protection at the state level. Amonk, NJ: M. E. Sharpe.

Sabatier, P. A., \& Mazmanian, D. (1980). The implementation of public policy: A framework for analysis. Policy Studies Journal, 8, 538-560.

Scheberle, D. (1997). Federalism and environmental policy: Trust and the politics of implementation. Washington, DC: Georgetown University Press.

Vogel, D. (1986). National styles of regulation. Ithaca, NY: Comell University Press.

Weaver, R. K., \& Rockman, B. A. (1993). Assessing the effects of institutions. In R. K. Weaver \& B. A. Rockman (Eds.), Do institutions matter? (pp. 1-41). Washington, DC: Brookings. 